Reprod. Nutr. Dévelop., 1982, 22 (4), 689-696.

\title{
Sodium and potassium balances and plasma aldosterone levels in newborn calves
}

\author{
A. SAFWATE, Marie-Jeanne DAVICCO $\left({ }^{*}\right)$, J.-P. BARLET $\left({ }^{*}\right)\left({ }^{1}\right)$, P. DELOST \\ E.R.A., C.N.R.S. 414, Endocrinologie du Développement, \\ Laboratoire de Physiologie Animale, Université de Clermont II, B.P. 45, 63170 Aubières. \\ (*) I.N.R.A., Theix, 63110 Beaumont.
}

Summary. This paper describes a balance study, performed during the first 7 days of postnatal life on 10 male Holstein $x$ Friesian calves born spontaneously at term. The relationship between sodium and potassium balances and plasma aldosterone levels were assessed during the postnatal period. The animals were put in metabolic cages immediately after birth for 7 days. Intakes of sodium and potassium and their plasma levels, as well as urinary and faecal excretion, were measured daily. Statistical (multiple regression) analysis of the results demonstrated that animal age accounted for $57 \mathrm{p} .100$ of the variations observed in the plasma aldosterone levels. Neither intake nor faecal and urinary excretions of sodium and potassium were correlated with plasma aldosterone concentrations in newborn calves. The high plasma levels of this hormone at the time of birth might be a result of labor.

\section{Introduction.}

Neonatal plasma aldosterone concentrations have been measured in several species. Previous studies have demonstrated high plasma aldosterone levels in newborn animals (Dlouha et al., 1973 ; Giry and Delost, 1974, 1977 ; Giry et al., 1979 : Dalle et al., 1978 ; Ferguson et al., 1979 ; Loctin, 1980 ; Moncaup et al., 1980) as well as in human neonates (Beitins et al., 1972 ; Dillon et al., 1976; Tochigi et al., 1976 ; Sparano et al., 1978 ; Sulyok et al., 1979). The reasons for these high plasma aldosterone concentrations at birth remain obscur.

No relationship between plasma potassium and sodium concentrations and plasma aldosterone levels could be demonstrated during the hours following parturition in calves (Safwate et al., 1980). In the work reported here we have studied the possible influence of electrolyte balance on plasma aldosterone levels during the first week of postnatal life in calves.

(1) Correspondence to : J.-P. Barlet, I.N.R.A., Theix, 63110 Beaumont. 


\section{Materials and methods.}

Animals. - The experiments were carried out on 10 male Holstein $\times$ Friesian calves, spontaneously born at term (278-280 days of pregnancy) and weighing $42.9 \pm 1.1 \mathrm{~kg}$ (mean \pm S.E.M.) at birth. Calves born between $6 \mathrm{a} . \mathrm{m}$. and $8 \mathrm{a} . \mathrm{m}$. were chosen so that after parturition they could be separated from their dams and housed immediately in metabolic cages for urine and faeces collection during the first week of postnatal life. The animals were fed twice daily. On the first day they received colostrum (from a previously collected pool of bovine colostrum ; 2.5 I per feeding). On the following days they were fed a milk replacer $(2.5-5$ I per feeding ; $130 \mathrm{~g}$ milk powder per $\mathrm{kg}$ of water) containing $13 \mathrm{~g}$ of potassium and $9 \mathrm{~g}$ of sodium per $\mathrm{kg}$ of dry matter.

During the experimental period, mean daily body weight gain was $600 \pm 80 \mathrm{~g}$. The quantities of colostrum or milk consumed daily by each calf were measured, and the urine and faeces from each, were collected daily and weighed. Samples of urine $(10 \mathrm{ml})$ were frozen until analysis. The faeces were dried at $103{ }^{\circ} \mathrm{C}$ for $48 \mathrm{hrs}$. A sample of the dry matter $(0.5 \mathrm{~g})$ was ashed at $380^{\circ} \mathrm{C}$ for $16 \mathrm{hrs}$, and ashes were dissolved in $3 \mathrm{~N} \mathrm{HCl}$. The resulting solution was stored at $4{ }^{\circ} \mathrm{C}$ until analysis.

Blood samples were collected by puncturing an external jugular vein within two minutes following delivery, then 12 and 24 hrs later. Afterwards, from day 2 to 7, they were collected once daily at 9 a.m. just before feeding. After microhematocrit measurement, the blood was centrifuged and the plasma frozen until analysis.

Assays. - Plasma aldosterone levels were determined by radioimmunoassay (Bayard et al., 1970; Giry and Delost, 1977). Thawed plasma samples were extracted with dichloromethane defatted at $-30^{\circ} \mathrm{C}$ with 70 p. 100 methanol and centrifuged at $3000 \mathrm{rpm}$.

The aldosterone was separated from the cortisol and cortisone by paper chromatography (Bush B5). Method recovery was determined by the addition of a known amount of radioactive $1,2-{ }^{3} \mathrm{H}$ aldosterone (New England Nuclear Corporation ; specific activity $40-60 \mathrm{Ci} / \mathrm{mmol}$ ) was $70 \mathrm{p}$. 100 . Sensitivity of the method was 9 p. 100 for 100 to $400 \mathrm{pg}$.

Urine and plasma osmolality measurements were made cryoscopically on fresh samples using a Fiske model G66 osmometer.

Sodium and potassium concentrations in plasma, urine and faeces were measured by flame emission spectrophotometry (Perkin-Elmer 400).

Statistical analysis. - The results are presented as the mean \pm SEM. Probability and significance were calculated by Student's $t$-test. Multiple regression analyses were also effected.

\section{Results.}

The hematocrit decreased from $44 \pm 3$ p. 100 immediately after birth to $36 \pm 2$ p. 1003 days later $(P<0.05)$, then remained stable until day 7 $(33 \pm 2$ p. 100) (fig. 1). 
FIG. 1. - Plasma hematocrit $(\mathrm{Ht})$, potassium (K) and sodium $(\mathrm{Na})$ levels, plasma and urine osmolality and plasma aldosterone levels in 10 male calves during the first 7 days of postnatal life (mean \pm SEM).

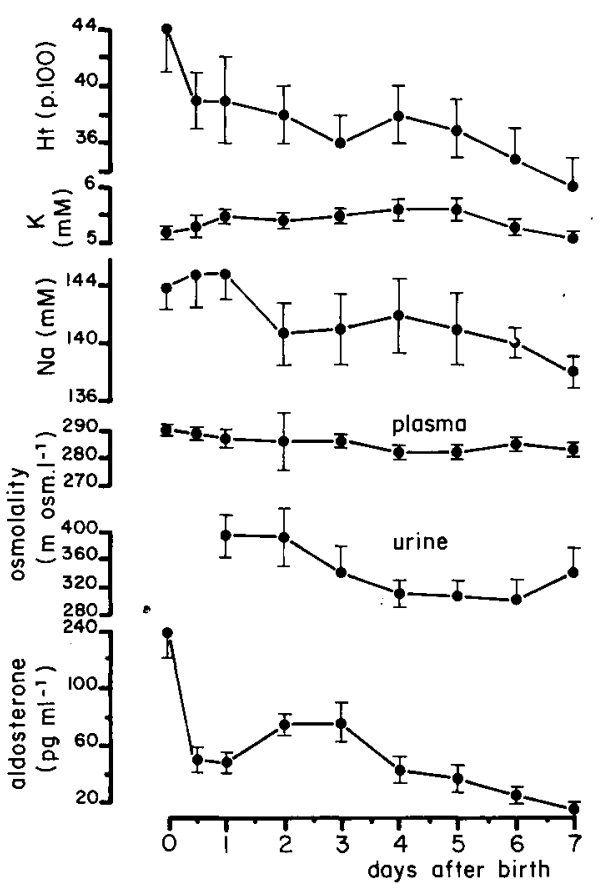

Plasma osmolality did not vary significantly from birth $(290 \pm 2 \mathrm{mOsm} / \mathrm{l})$ to day 7 (282 $\pm 2 \mathrm{mOsm} / \mathrm{l})$.

Plasma potassium levels did not vary significantly from birth $(5.2 \pm 0.1 \mathrm{mM})$ to day $7(5.2 \pm 0.1 \mathrm{mM})$.

Plasma sodium levels decreased from $144 \pm 2 \mathrm{mM}$ at birth to $139 \pm 1 \mathrm{mM}$ $(P<0.05)$ on day 6 to $137 \pm 1 \mathrm{mM}(P<0.05)$ on day 7 (fig. 1$)$.

During the first week of postnatal life, daily sodium and potassium intakes increased from 3.3. $\pm 0.5 \mathrm{~g}$ and $7 \pm 1 \mathrm{~g}$, respectively, during day 1 to $7.8 \pm 0.5 \mathrm{~g}$ $(\mathrm{P}<0.01)$ and $19 \pm 1 \mathrm{~g}(\mathrm{P}<0.01)$, respectively, on day 7 .

Daily urinary sodium excretion increased from $1.1 \pm 0.5$ during day 1 to $3.5 \pm 0.5 \mathrm{~g}(\mathrm{P}<0.01)$ during day 3 , then remained stable until day $7(5.3 \pm 0.6 \mathrm{~g})$. Simultaneously, daily faecal sodium excretion decreased from $1.1 \pm 0.2 \mathrm{~g}$ during day 1 to $0.3 \pm 0.1(P<0.01)$ during day 3 , then remained stable until day 7 $(0.3 \pm 0.1 \mathrm{~g})$ (table 1). Thus, during the first week of postnatal life daily sodium balance was positive, except on day 4 (fig. 2).

No significant change in daily potassium excretion was observed between day $1(2.5 \pm 1.5 \mathrm{~g})$ and day $2(2.9 \pm 0.7 \mathrm{~g})$. Then daily urinary potassium excretion increased gradually until day $6(13.3 \pm 0.7 \mathrm{~g} ; \mathrm{P}<0.01)$ and did not change during day $7(10 \pm 0.5 \mathrm{~g})$. Daily faecal potassium excretion decreased from day $1(0.2 \pm 0.07 \mathrm{~g})$ until day $5(0.09 \pm 0.01 \mathrm{~g} ; \mathrm{p}<0.01)$, then increased until day $7(0.4 \pm 0.01 \mathrm{~g} ; \mathrm{P}<0.01)$ (table 1$)$. Potassium balance was always positive during the first week of postnatal life (fig. 2). 
TABLE 1

Changes in sodium and potassium intake ( $\mathrm{g} /$ day) and excretion $(\mathrm{g} /$ day) in 10 male calves during the first 7 days of postnatal life (mean \pm SEM)

\begin{tabular}{|c|c|c|c|c|c|c|}
\hline \multirow{3}{*}{ Days } & \multicolumn{3}{|c|}{ Sodium } & \multicolumn{3}{|c|}{ Potassium } \\
\hline & \multirow[t]{2}{*}{ Intake } & \multicolumn{2}{|c|}{ Excretion } & \multirow[t]{2}{*}{ Intake } & \multicolumn{2}{|c|}{ Excretion } \\
\hline & & Urine & Faeces & & Urine & Faeces \\
\hline 1 & $\begin{array}{c}3.3 \\
\pm \\
0.5\end{array}$ & $\begin{array}{c}1.1 \\
\pm \\
0.5\end{array}$ & $\begin{array}{r}1.1 \\
\pm \\
0.2\end{array}$ & $\begin{array}{l}7.0 \\
\pm \\
1.0\end{array}$ & $\begin{array}{l}2.5 \\
\pm \\
1.5\end{array}$ & $\begin{array}{c}0.2 \\
\pm \\
0.01\end{array}$ \\
\hline 2 & $\begin{array}{c}3.7 \\
\pm \\
0.3\end{array}$ & $\begin{array}{c}1.5 \\
\pm \\
0.4\end{array}$ & $\begin{array}{c}0.5 \\
\pm \\
0.01\end{array}$ & $\begin{array}{l}8.3 \\
\pm \\
0.5\end{array}$ & $\begin{array}{l}2.9 \\
\pm \\
0.7\end{array}$ & $\begin{array}{c}0.2 \\
\pm \\
0.1\end{array}$ \\
\hline 3 & $\begin{array}{c}3.7 \\
\pm \\
0.4\end{array}$ & $\begin{array}{c}3.5 \\
\pm \\
0.5\end{array}$ & $\begin{array}{c}0.3 \\
\pm \\
0.01\end{array}$ & $\begin{array}{l}8.6 \\
\pm \\
0.7\end{array}$ & $\begin{array}{l}5.8 \\
\pm \\
0.3\end{array}$ & $\begin{array}{c}0.2 \\
\pm \\
0.01\end{array}$ \\
\hline 4 & $\begin{array}{c}4.7 \\
\pm \\
0.5\end{array}$ & $\begin{array}{c}4.6 \\
\pm \\
0.7\end{array}$ & $\begin{array}{c}0.2 \\
\pm \\
0.01\end{array}$ & $\begin{array}{l}11 \\
\pm \\
1.2\end{array}$ & $\begin{array}{l}6.8 \\
\pm \\
0.4\end{array}$ & $\begin{array}{c}0.1 \\
\pm \\
0.01\end{array}$ \\
\hline 5 & $\begin{array}{c}6.5 \\
\pm \\
0.8\end{array}$ & $\begin{array}{c}3.7 \\
\pm \\
0.3\end{array}$ & $\begin{array}{c}0.1 \\
\pm \\
0.01\end{array}$ & $\begin{array}{c}15.9 \\
\frac{ \pm}{2}\end{array}$ & $\begin{array}{l}9 \\
\pm \\
1.3\end{array}$ & $\begin{array}{c}0.2 \\
\pm \\
0.01\end{array}$ \\
\hline 6 & $\begin{array}{c}7.8 \\
\pm \\
0.5\end{array}$ & $\begin{array}{c}4.2 \\
\pm \\
0.3\end{array}$ & $\begin{array}{c}0.2 \\
\pm \\
0.01\end{array}$ & $\begin{array}{c}19.4 \\
\pm \\
\frac{ \pm}{1.9}\end{array}$ & $\begin{array}{c}13.3 \\
\pm \\
0.7\end{array}$ & $\begin{array}{c}0.2 \\
\pm \\
0.01\end{array}$ \\
\hline 7 & $\begin{array}{c}7.8 \\
\pm \\
0.4\end{array}$ & $\begin{array}{c}5.3 \\
\pm \\
0.6\end{array}$ & $\begin{array}{c}0.3 \\
\pm \\
0.01\end{array}$ & $\begin{array}{c}19 \\
\pm \\
\frac{1}{1}\end{array}$ & $\begin{array}{l}10 \\
\pm \\
0.5\end{array}$ & $\begin{array}{c}0.4 \\
\pm \\
0.1\end{array}$ \\
\hline
\end{tabular}

Urinary osmolality decreased from $375 \pm 20 \mathrm{mOsm} / \mathrm{l}$ during day 1 to $310 \pm 18 \mathrm{mOsm} / \mathrm{l}$ during day $4(P<0.01)$, then remained stable until day 7 (340 $\pm 32 \mathrm{mOsm} / \mathrm{l}$ ) (fig. 1).

Plasma aldosterone concentrations decreased from $138 \pm 18 \mathrm{pg} / \mathrm{ml}$ at birth to $50 \pm 9 \mathrm{pg} / \mathrm{ml} 12 \mathrm{hrs}$ later $(\mathrm{P}<0.01)$. However, plasma aldosterone levels measured at $48 \mathrm{hrs}(75 \pm 7 \mathrm{pg} / \mathrm{ml})$ and $72 \mathrm{hrs}(75 \pm 13 \mathrm{pg} / \mathrm{ml})$ were higher than those measured at $24 \mathrm{hrs}(49 \pm 8 \mathrm{pg} / \mathrm{ml} ; \mathrm{P}<0.05)$. Plasma aldosterone levels then decreased gradually until day $7(14 \pm 5 \mathrm{pg} / \mathrm{ml} ; \mathrm{P}<0.01)$ (fig. 1$)$.

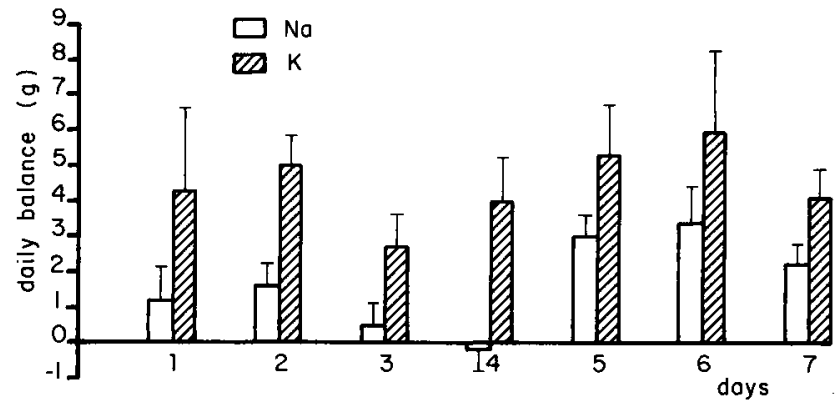

FIG. 2. - Sodium (Na) and potassium (K) balances in 10 male calves during the first 7 days of postnatal life (mean \pm SEM). 
Multiple regression analysis of the results (plasma aldosterone concentration, hematocrit, urine osmolality, sodium and potassium intakes, urinary and faecal sodium and potassium excretions, sodium and potassium balances) demonstrated that animal age $(x)$ was responsible for 57 p. 100 of the variance observed for plasma aldosterone levels $(y)$ after birth $(y=94.2-12.02 x ; r=-0.76$; $P<0.01$ ). No relationship could be demonstrated between plasma aldosterone concentration and any of the other parameters measured.

\section{Discussion.}

To our knowledge, this is the first time that sodium and potassium balances have been measured in calves immediately after birth. Other electrolyte balances performed in calves were done on 1 to 3 week-old calves (Fayet, 1968, 1971 ; Fisher and De La Fuente, 1972) or in starved newborn calves (Dalton, 1967) to compare sodium and potassium metabolism in healthy and dehydrated animals. However the values measured in our animals during the last days of the experimental period are similar to those obtained by other workers in healthy Ayrshire (Dalton, 1967 ; Fisher and De La Fuente, 1972), Jersey or Friesian calves (Fayet, 1968, 1971). Our results clearly indicate that during the first week of postnatal life, faecal sodium losses in healthy calves fall from birth, whereas urinary losses rise (table 1). A possible explanation for this is that in newborn calves, as in newborn pigs, sodium reabsorption from the intestine is stimulated by the high initial aldosterone plasma levels (Cremashi et al., 1979 ; Ferguson et al., 1979). The absence of such an effect in the kidney may reflect either the insensitivity of the renal tubules ot aldosterone at this age, or other changes in renal function over the first days of postnatal life.

No significant variation in plasma sodium and potassium concentrations occurred in calves during the first week of postnatal life (Safwate et al., 1980, fig. 1). We have previously shown that a high potassium intake can increase plasma potassium aldosterone concentrations in dairy heifers (Safwate and Barlet, 1981). However no relationship can be established between plasma potassium (or sodium) concentrations and aldosteronemia during the first week of postnatal life in calves (Safwate et al., 1980 ; Fig. 1). Similar results have been reported in guinea-pigs (Giry and Delost, 1977), foals (Giry et al., 1979) and mice (Loctin, 1980). In 7 foetal lambs (90-139 days of pregnancy) chronically catheterized in utero, intravenous infusion of aldosterone altered the excretion of sodium and potassium in foetal urine (Lingwood et al., 1978). However the blood aldosterone concentration of the sheep foetus is not elevated by increasing plasma potassium (Wintour et al., 1979). Similarly in foetal (last month of pregnancy) and newborn (first month of postnatal life) lambs, no relationship could be established between plasma sodium and potassium concentrations and plasma aldosterone levels (Moncaup et al., 1980).

The daily intake and urinary and fecal excretion of sodium and potassium were not correlated with plasma aldosterone levels. The statistical (multiple regression) analysis of the results demonstrates that the age of the animals 
accounted for 57 p. 100 of the variations observed in plasma aldosterone levels. Thus the reasons for the high plasma aldosterone concentration observed at the time of birth (fig. 1) remain unknown. The regulation of plasma aldosterone levels is still poorly understood in newborn mammals. Higher plasma renin activity (PRA) has been measured in human babies born by vaginal delivery (Hayduck et al., 1972 ; Katz et al., 1974 ; Dillon et al., 1976 ; Sparano et al., 1978) than in those delivered by cesarean section (Lammintausta et al., 1977; Lumbers and Reid, 1977 ; Oparil et al., 1978). Plasma concentrations of angiotensin II are also higher in the nursing infant than in the adult (Kotchen et al., 1972 ; BroughtonPipkin and Symonds, 1977). Similarly, in dogs (Granger et al., 1971), rabbits (Pernollet et al., 1979) and lambs (Broughton-Pipkin et al., 1974), plasma PRA and angiotensin $\|$ levels are higher during the neonatal period than in adult animals. However, no relationship could be demonstrated between the reninangiotensin system and plasma aldosterone levels in human neonates (Godard et al., 1976 ; Sparano et al., 1978).

Elevated plasma aldosterone concentrations have also been observed immediately after birth in young mice born by vaginal delivery, but not in those delivered by cesarean section at the same time of pregnancy (day 20) (Loctin, 1980). Thus, in the calves used in this experiment and spontaneously born at term, as in mice, parturition labor might induce a surge in plasma aldosterone levels. The physiological role of such high plasma aldosterone levels remains unknown.

Reçu en janvier 1982.

Accepté en mars 1982

Acknowledgements. - We gratefully acknowledge the assistance of $\mathrm{R}$. Dabert and R. Roux. This work was supported in part by DGRST (contract $81 \mathrm{~L} 1316$ ).

Résumé. Dix veaux mâles Holstein $\times$ Frisons, nés spontanément à terme, ont été placés en cages à bilan individuelles, immédiatement après la naissance jusqu'à la fin du $7^{e}$ jour de vie postnatale, afin d'observer l'influence éventuelle des paramètres du bilan du soidum et du potassium sur les variations postnatales de l'aldostéronémie. Les quantités consommées, l'excrétion urinaire et fécale ainsi que les taux plasmatiques du sodium et du potassium ont été mesurés quotidiennement, ainsi que l'osmolarité urinaire et l'hématocrite. L'analyse statistique des résultats (par test de régressions multiples) indique que l'évolution de l'âge des animaux intervient pour 57 p. 100 des variations observées au niveau de l'aldostéronémie. II semble donc que l'aldostéronémie très élevée au moment de la naissance soit une conséquence du travail associé à la parturition.

\section{References}

BAYARD F., BEITINS J. Z,, KOWARSKI A., MIGEON C. J., 1970. Measurements of plasma aldosterone by radioimmunoassay. $J$. clin. Endocrinol. Metab., 31, 1-6.

BEITINS J. Z., BAYARD F., LEVITSKY L., ANLES I. G., KOWARSKI A., MIGEON C. J., 1972. Plasma aldosterone concentrations at delivery and during the newborn period. J. clin. Invest., 51, 386-394. 
BROUGHTON-PIPKIN F. B., KIRPATRICK S. M. L., LUMBERS E. R., MOTT J. C., 1974. Renin and angiotensin levels in foetal, newborn and adult sheep. J. Physiol. (London), 241, 575588.

BROUGHTON-PIPKIN F. B., SYMONDS E. M., 1977. Factors affecting angiotensin II concentrations in the human infants at birth. Clin. Sci., 52, 449-454.

CREMASHI D., FERGUSON D. R., HENIN S., JAMES P. S., MEYER G., SMITH M. W., 1979. Postnatal development of amiloride sensitive sodium transport in pig distal colon. J. Physiol. (London), 292, 481-494.

DALLE M., GIRY J., GAY M., DELOST P., 1978. Perinatal changes in plasma and adrenal corticosterone and aldosterone concentrations in the mouse. J. Endocr., 76, 303-309.

DALTON R. G., 1967. The effect of starvation on the fluid and electrolyte metabolism of neonatal calves. Br. vet. J., 123, 237-246.

DILLON M. J., GILLIN M., RYNESS J. M., DE SWIFT M., 1976. Plasma renin activity and aldosterone concentration in the human newborn. Arch. Dis. Child, 51, 537-540.

DLOUHA H., ERDOSOVA R., KRAUS M., SKOPKOVA J., 1973. The effect of sodium intake on maternal milk electrolyte and aldosterone, corticosterone and $18 \mathrm{OH}$ deoxycorticosterone production in offspring of rats. Biol. Neonate, 22, 38-49.

FAYET J. C., 1968. Recherches sur le métabolisme hydrominéral chez le veau normal ou en état de diarrhée. I. Excrétions fécale et urinaire. Evolution de l'appétit et du poids corporel. Rech. vét., 1, 99-108.

FAYET J. C., 1971. Plasma and faecal osmolality, water kinetics and body fluids compartments in neonatal calves with diarrhoea. Br. vet. J., 127, 37-43.

FERGUSON D. R., JAMES P. S., PATERSON J. Y. F., SAUNDERS J. C., SMITH M. W., 1979. Aldosterone induced changes in colonic sodium transport occurring naturally during development in the neonatal pig. J. Physiol. (London), 292, 495-504.

FISHER E. W., DE LA FUENTE G. H., 1972. Water and electrolyte studies in new-born calves with particular reference to the effects of diarrhoea. Res. vet. Sci., 13, 315-322.

GIRY J., DELOST P., 1974. Evolution de l'aldostéronémie du foetus et du nouveau-né de cobaye au cours de la période périnatale. C. R. Acad. Sci. Paris, sér. D, 279, 2087-2090.

GIRY J., DELOST P., 1977. Changes in the concentrations of aldosterone in the plasma and adrenal glands of the foetus, the newborn and the pregnant guinea-pig during the perinatal period. Acta endocrinol., 84, 133-141.

GIRY J., KHALDOUN M., TOURNAIRE C., BARLET J. P., MARTIN-ROSSET W., DELOST P., 1979. L'aldostérone chez la jument en fin de gestation et chez le poulain au cours de la période néonatale. J. Physiol. (Paris), 75, 28A.

GODARD C., GAILLARD R., VALLOTON M. B., 1976. The renin-angiotensin-aldosterone system in mother and fetus at term. Nephron, 17, 353-360.

GRANGER P., ROJO-ORTEGA J. M., PEREZ S. C., BOUCHE R., GENEST J., 1971. The reninangiotensin system in newborn dogs. Canad. J. Physiol. Pharmacol., 49, 134-138.

HAYDUCK K., KRUSE D. K., HENGES R., UNBEHAV V., 1972. Plasma renin concentration at delivery and during the newborn period in humans. Experientia, 28, 1489-1490.

KATZ F. H., BECK P., MAKOWSKI E. L., 1974. The renin-aldosterone system in mother and fetus at term. Am. J. Obstet. Gynecol., 118, 51-55.

KOTCHEN T. A., STRIKLAND A. L., RICE T. W., WALTERS D. R., 1972. A study of the reninangiotensin system in newborn infants. $J$. pediatrics, 80, 938-946.

LAMMINTAUSTA R., ERONEN M. D., ERRKOLA R., 1977. The effect of normal labor on the reninangiotensin system in newborn infants. J. Pediatrics, 80, 938-946.

LINGWOOD B., HARDY K. J., COGHLAN J. P., WINTOUR E. M., 1978. Effect of aldosterone on urine composition in the chronically cannulated ovine foetus. J. Endocr., 76, 553-554.

LOCTIN J., 1980. Obtention, mortalité, croissance et fonction minéralocorticoïde du prématuré expérimental de souris. Th. $3^{\text {e }}$ cycle, Clermont-Ferrand, $246 \mathrm{pp}$.

LUMBERS E. R., REID G. C., 1977. Effects of vaginal delivery and cesarian section on plasma renin-activity and angiotensin. II. Levels in human umbilical cord blood. Biol. Neonate, 31, 127-134.

MONCAUP M., GIRY J., BARLET J.-P., LEFAIVRE J., DELOST P., 1980. Aldosterone metabolism in pregnant ewes and fetal and newborn lambs. Reprod. Nutr. Dévelop., 20, 277-286. 
OPARIL S., KOERNNER T., LINDHEIMER M. D., 1978. Plasma angiotensin converting enzyme activity in mother and fetus. J. clin. Endocr. Metab., 46, 434-438.

PERNOLLET M. G., DEVYNCK M. A., MAC DONALD C. J., MEYER P., 1979. Plasma renin activity and adrenal angiotensin $I I$ receptors in fetal, newborn adult and pregnant rabbits. Biol. Neonate, 36, 119-127.

SAFWATE A., BARLET J.-P., 1981. Influence d'un apport important de potassium à des génisses d'élevage. Bull. Techn. C.R.Z.V. Theix-I.N.R.A., $\mathrm{n}^{\circ}$ 43, 31-32.

SAFWATE A., DAVICCO M. J., BARLET J.-P., DELOST P., 1980. Plasma sodium, potassium and aldosterone levels in newborn calves. J. Physiol. (Paris), 76, 906-907.

SPARANO F., SCIARRA F., NATOLI G., MERWRI A., ODOARDI A., COLANGELO E., 1978. Behaviour of plasma renin activity and aldosterone during the first $72 \mathrm{~h}$ of life. Clin. Endocrinol., 8, 207-212.

SULYOK E., NEMETH M., TENYI I., CSABA I. F., VARGA F., GYORY E., THORZO V., 1979. Relationship between maturity, electrolyte balance and the function of the renir-angiotensinaldosterone system in newborn infants. Biol. Neonate, 35, 60-65.

TOCHIGI B., 1976. Studies on aldosterone concentration of maternal, fetal and neonatal plasma during pregnancy, parturition and neonatal period. Nichidai lgaku Zasshi, 35, 857-868.

WINTOUR E. M., BARNES E. M. A., CAHILL F., HARDY K. J., HORACEK I., SCOGGINS B. A., 1979. Potassium : aldosterone relationships in pregnant ewes and chronically cannulated ovine fetuses. Pediat. Res., 13, 265-267. 